\title{
Start-up Capital Source and Credit Access Participation of Household Nonfarm Enterprises in Nigeria: Evidence from Logistic Regression Model
}

\author{
Obed I. Ojonta
}

University of Nigeria, Nigeria

obed.ojonta@unn.edu.ng

Divine N. Obodoechi

University of Nigeria, Nigeria

divine.obodoechi@unn.edu.ng

Paschaline N. Ugwu

University of Nigeria, Nigeria

paschaline.ugwu@unn.edu.ng

The main focus of this study is to estimate the influence of the main startup capital source on credit access participation by household nonfarm enterprises. The General Household Survey data for 2018 was adopted to construct a measure of credit access participation. Through binary logistic regression estimation, the result shows that main start-up capital source positively and significantly influences credit access by household nonfarm businesses in Nigeria. This also implies that household nonfarm enterprises that borrowed as main start-up capital source have better chances of credit access participation when compared to those household nonfarm enterprises who do not borrow. However, this study suggests that there is a need for policies that motivate individuals or a group of individuals to borrow as their main start-up capital source in Nigeria, with a view to strengthening their operations on a sustainable basis.

Key Words: credit access, household, enterprise, binary logistic regression, Nigeria

JEL Classification: E51, G5

(co) BY.SA https://doi.org/10.26493/1854-6935.19.249-267

\section{Introduction}

Nigeria is a developing nation among lower/middle income economies that largely depends on the production and distribution of goods and services (Kpokiri, Taylor, and Smith 2020). Such business activities are predominantly among individuals of low per capita income in the country. 
These categories of individuals are believed to be very poor and, as well, need financial support as start-up capital for business investment. It has been found that Nigeria, having been endowed with natural and human resources, is presently known as the poverty headquarters of the world with more than 93 million people in the population living in poverty (Urama and Iheonu 2019). The state of poverty in developing countries like Nigeria should have guaranteed individuals borrowing as a source of start-up capital for business investment. In spite of the fact that borrowing as a source of start-up capital contributes to expansion of business, promotes investment and guarantees profit, it has been found that enterprises in Nigeria are still facing challenges of access to finance resulting from the inability to provide collateral for robust and adequate business investment. Several researchers have argued that deprivation in household enterprises to credit access as a source of start-up capital for investment has been found to be a serious problem that is confronting efficient and effective business activities in Nigeria. The trickledown effect originating from inadequate access to finance has created a serious impediment to firms' or enterprises' performance, and includes decreasing output production, decreasing employment opportunities and a high level of poverty. These impediments have also negatively affected the willingness of enterprises to have access to credit as the main source of startup capital for investment (Chauke et al. 2013). Often, these challenges of start-up capital have been traced to asymmetric information as a cause of poor performance of household nonfarm enterprises (HNES) (Hoff and Stiglitz 2000; Erasmus and Scheepers 2008; Aver 2008).

Indeed, main sources of start-up capital and access to credit by HNES in Nigeria have been a major issue of concern in the Nigerian economy. This issue of concern requires attention to ensure that small and medium enterprises (smes) are promoted in the Nigerian economy. Additionally, studies by Ali and Peerlings (2012), Haggblade, Hazell, and Reardon (2007), Lanjouw (2007), Bigsten et al. (2003), and Beck and DemirgucKunt (2005) show that access to credit plays a pivotal role in the performance of HNES in Nigeria, such as creation of employment opportunities, supporting enterprises to catch up with urgent needs, and enhancing start-up capital for investment as well as relief for payment of debt.

However, considering the present outbreak of the Covid-19 pandemic and low per capita income in developing countries, the willingness for credit access as a main start-up capital source is likely to be significant. This, however, implies that if household nonfarm enterprises eventually 
have access to credit, it will go a long way in boosting output production, increasing consumption, and creating employment as well as reducing the poverty rate. The reduction in poverty rate will motivate investment that will boost economic activities such that the impact can reduce the widespread consumption inequality among household nonfarm enterprises.

The Nigerian government in 2015, under the government of former President of the Federal Republic of Nigeria, Dr. Goodluck Ebele Jonathan, made enormous efforts to ensure that the issue as concerns credit access policies are made available to guarantee borrowers easy credit access participation or any other form of support to promote entrepreneurship. Some of these policies included the establishment of the National Collateral Registry and Credit Control policies to ensure that borrowers or enterprises are provided with credit at reasonable interest rates. These policies were promulgated by the government primarily for poverty alleviation and empowerment of small and medium enterprises in Nigeria. The surprise point is that all these policies as instituted by the government appear not to handle the problems associated with credit access participation and main start-up capital sources in Nigeria. The large population of HNES in Nigeria still suffer a serious problem in participation in credit access and such problems include provision of collateral and surety in case of default to pay back the loan (Ugwuanyi 2012). It is evident that the main start-up capital source for HNEs has been a serious issue in most low income countries like Nigeria (Etumeahu, Okekeke, and Ukwandu 2009). The majority of these enterprises have decided to look for financial freedom elsewhere due to their inability to meet the conditions that will guarantee them the ability to borrow. The deprivation of credit access appears to be widening in Nigeria over the past one and a half decades following the emergence of Covid-19 and a stagnant real sector that could intervene to share the benefits of growth to all population groups (Akanni and Gabriel 2020).

This study departs from previous studies in the literature that have been carried out on credit access in Nigeria from various perspectives. Many such studies, for instance Rahji and Adeoti (2010), Haruna (2007), and Olagunju (2007), focused on how access to credit influences employment creation performance. A few, like Chinanuife et al. (2019), Nwosu and Orji (2016), Nwosu and Orji (2017), and Orji et al. (2019) conducted studies on access to credit based on aggregate enterprises in Nigeria. Further studies such as Adepoju, Omolade, and Obayelu (2019), Loening, Ri- 
jkers, and Söderbom (2008), Nwosu et al. (2020), and Ojonta and Ogbuabor (2021), carried out studies on how access to credit influences the performance of nonfarm enterprises using cross sectional data. These studies have not considered the opposite, how access to credit could be influenced by other factors in Nigeria. To date, the influence of main start-up capital sources on credit access performance of HNES in Nigeria is yet to be investigated using logistic regression model estimation. It is the goal of this study to fill this important gap in the literature in order to provide evidence that can support government policies for the household nonfarm sector in the country. Thus, the main objective of this study is to examine how the main start-up capital source influences credit access of HNES in Nigeria.

Other studies, such as Rahji and Adeoti (2010), Ajani and Omonona (2009), Anyanwu (1994), Essien and Arene (2014), Haruna (2007), Oboh and Kushwaha (2009), and Ugwuanyi (2012) were very close to the present study. These studies examined the determinant factors that influence credit access using cross sectional data but, however, failed to consider the important role of main start-up capital sources of household nonfarm enterprises in influencing participation in credit access.

The remaining sections of this paper proceed as follows. The next section presents an overview of the extant literature from both theoretical and empirical perspectives, while Section 3 provides the data and the method of analysis employed in this study, detailing the model specification. The empirical results are shown and discussed in Section 4, while Section 5 concludes the paper.

\section{Review of Literature}

\section{THEORETICAL LITERATURE}

Many theories established in the literature support this investigation on the relationship between main start-up capital source and access to credit participation by household non-farm enterprises (HNES). These economic theories include credit rationing theory, financial intermediation theory, and imperfect information theory (Hoff and Stiglitz 1990; Stiglitz and Weiss 1981; Benston and Smith 1976).

\section{Credit Rationing and Constraint Theory}

Stiglitz and Weiss (1981) propounded a theory of credit rationing and constraint. The theory was established to understudy the risk of rationing 
loans by lenders on business activities. It explained that when there is rationing in issuing loans to an individual or a firm, such rationing could cause a serious constraint on business expansion. It explained that the consequences of rationing loans to borrowers could lead to various forms of shocks such as unbalanced inclusiveness and distorted growth in business transactions.

The theory also explained that loan discrimination among borrowers either as an individual or group of individuals, even when such individuals have the willingness to pay back at higher interest, is a serious impediment to business expansion. The theory as proposed by Stiglitz and Weiss (1981) established that individuals or firms would like to borrow provided the lender is willing to offer such credit with a lower interest rate and collateral.

\section{Information Asymmetry Theory}

The theory of information asymmetry was propounded by Hoff and Stiglitz (1990). It was developed to address issues of information on business transactions. It established that when there is imperfect information on business transactions, such imperfection has the likelihood to result in an information problem. The theory explained that the effect of such imperfect information within the financial market could lead to various factors such as moral hazard and adverse selection. The theory as proposed by Hoff and Stiglitz (1990) defined the effects of information problems in three categories within the financial market: screen, incentive and enforcement problems. The screen problem is used to measure the determination of the extent of the default while the incentive and enforcement problems are used to measure the cost conceived in ensuring credit contracts are honoured and the cost incurred in monitoring of credit beneficiaries to ensure loan repayment, respectively.

\section{Transaction Cost Theory}

The transaction cost theory was propounded by Benston and Smith (1976). The theory portrayed the argument that financial intermediaries are in business to maximize profit and utilize economies of scale with the aid of technological innovation. The major characteristics associated with transaction cost theory are the costs involved in processing and gathering data (information) that is required to reach a decision during the transaction process, policing and enforcement of contracts. 
Many studies on credit access and the performance of household enterprises have been conducted and documented in the literature for both developing and developed economies. For example, in the developing economy, Chisasa (2019) performed a research on how factors like the capital structure of the farmer, family net worth and household income influence a farmer's access to bank credit, using a cross sectional dataset in South Africa. The results show that they positively and significantly influence the farmer's access to bank credit.

In Sri Lanka, Gamage (2013) used the binary logistic regression model to estimate how location of the firm, availability of audited financial statements and the owner-managers' perception of access to finance influence access to bank finances for small and medium-sized enterprises. The study found that these variables positively and significantly influence access to bank finances for small and medium-sized enterprises. In another study, Aga and Reilly (2011), using probit model estimation, stated that a firm's location, membership of a business association, age, size, the sector in which it operates, and accounting record maintenance are important factors that influence credit access in Ethiopia.

According to Ololade and Olagunju (2013), sex, marital status, lack of guarantor, and high interest rates are the important factors that influence credit access in Nigeria. Ojonta and Ogbuabor (2021) also conducted a study on how other factors of household nonfarm enterprises influence access to credit in Nigeria using multinomial model estimation.

Osano and Languitone (2016) used descriptive and inferential research design and found that the structure of the financial sector, awareness of funding opportunities, collateral requirements and small business support services are important factors that influence credit access by small and medium enterprises (smes) in Mozambique.

Chauke et al. (2013) conducted a study of smallholder farmers in South Africa using logistic regression model estimation. The result reports that need for credit, attitude towards risk, distance between lender and borrower, perception of loan repayment, perception of lending procedures and total value of assets are the important factors that influence credit access.

In the case of studies in the developed economy, Quach and Mullineux (2007), Afrin, Islam, and Ahmed (2009), Mach and Wolken (2011), Bauchet and Morduch (2013), Luan and Bauer (2016), Chowdhury and 
Alam (2017), Herkenhoff (2019), and Sahu (2017) focused on how credit access influences other indicators of household characteristics.

Indeed, the main focus of this present study is, firstly, to ascertain the influence of the main start-up capital source on credit access participation of household nonfarm enterprises using binary model estimation and a cross-sectional household survey dataset. Secondly, it is to ascertain other indicators that influence credit access participation of household nonfarm enterprises. Overall, this paper estimates the influence of the main start-up capital source on credit access participation of household nonfarm businesses in Nigeria.

\section{Theoretical Framework}

The subject of this study adopts the theoretical framework of credit rationing and constraint theory that was proposed by Stiglitz and Weiss (1981). The theory has been found most suitable to address the general content of this paper. The theory, however, explained how two different types of individuals are qualified to participate when dealing with credit rationing and constraint. The theory also found that such individuals are regarded as potential borrowers who have equal capacity to pay back, but while some have access to finance, others do not, even when they are willing to fulfil the agreement in terms of returns on investment with a higher interest rate. Thus, it is obvious that certain groups of individuals or firms have not adopted the position to guarantee them adequate access to credit, not regarding the prevailing level of interest rate existing in the current economy. Most importantly, the theorists, however, take note of the situations in which potential borrowers are deprived of the power to access the credit market completely by lenders, even when they have the capacity and willingness to pay back the loan for high rate of interest not considering the current prevailing interest in the market economy. These decisions on the part of lenders to advance inadequate access to credit by enterprises through credit advancement without taking into consideration the ability of an individual or firm in loan repayment at coverage of higher rate of interest can have a great influence on participation by enterprises borrowing as source of start-up capital.

Basically, when borrowing by enterprises as source of start-up capital is not given adequate attention and consideration as an important factor to promote access to credit, the trickledown effect could endanger the prospects of such enterprises. Such effects have the likelihood to develop serious problems of both moral hazard and adverse selection re- 
sulting from price failure and poor market performance. The price failure and poor market performance in the market caused by moral hazard will jeopardise the positive performance of the firm or enterprise. However, when enterprises are able to have credit access as a source of start-up capital, it will enhance the building capacity to borrow and by doing so, there will be employment opportunities, offering financial freedom, poverty reduction and food security (Haggblade, Hazell, and Reardon 2007; Lanjouw 2007; Ali and Peerlings 2012) which will provide support for promotion of flexibility in allocation of resources and reduction of cash flow (Bigsten et al. 2003). Additionally, when enterprises are provided with credit access it will support job creation and drive capital for investment.

Thus, Stiglitz and Weiss's (1981) theory explained that lenders' inability to promote enterprises through borrowing could have the likelihood of affecting business transactions and access to credit. When business transactions are greatly affected, the trickledown effect, which includes high poverty, a high unemployment rate and high dependency ratio, will largely increase. If not given adequate attention it could also cause a serious impediment to expansion of businesses in underdeveloped economies like Nigeria (Ugwuanyi 2012). Thus, Stiglitz and Weiss's (1981) theory provided a better evidence of the underlying model of this study.

\section{Data Descriptions and Methodology}

\section{DATA DESCRIPTION}

The General Household Survey Panel, published in 2018-2019 by the National Bureau of Statistics (2018) in collaboration with the Federal Ministry of Agriculture and Rural Development and the World Bank, is the dataset used for analysis in this study. The survey is a fourth wave household field panel survey targeting all 36 federal states, plus Abuja, the Federal Capital Territory.

The sample studied was designed to use the Local Government Area as the reporting domain for the General Household Survey. The sample design for the survey, however, also enabled the provision of estimates at national, geo-political and state level. The sampling frame for all the local government area which is 774 in numbers in Nigeria employed the enumeration area partitioned by the National Bureau of Statistics. The survey used a multi-stage stratified sample design to capture observations for 3919 households. However, some of the observations that were missing from the place of their location during the survey contribute to the 
sample size of 244 observations for credit access of household nonfarm enterprises.

Since this study focused on main start-up capital sources and credit access of household nonfarm enterprises, this paper will make use of the available data of a sample size of 244 as contained in the survey. To achieve a robust, and avoid getting a spurious, result, this study endeavours to take into consideration the outlier issues and homogeneity problems. In ascertaining that, 18 outliers were removed from the considered observations.

\section{MODEL SPECIFICATION}

The binary logistic regression model is a mutual exclusive event used when the dependent variable is categorised into two events, such that the occurrence of one event will affect the other while the independent variables take the value either discrete, continuous or both variables (Verbeek 2004). These assumptions are the reasons for adopting a binary logit model to estimate the influence of the main start-up capital source on credit access participation by household nonfarm enterprises in Nigeria. Since credit access participation by household nonfarm enterprises is a dummy variable with two categories (dichotomous), this study takes the modelling approach conducted by Astari and Kismiantini (2019). In the binary logit model adopted for this study, we code $\pi$ to stand for credit access participation by household nonfarm enterprises, while $x_{i}$ is coded to stand for the set of independent variables. Hence, the binary regression model for this study is coded as two outcomes in measuring the main start-up capital source. This implies that the binary regression model is suitable to determine the probability that a firm $i$ has one of the $j$ mutually exclusive events of credit access $(1=$ Yes; $2=$ No).

Looking at probability assumption by Justino, Litchfield, and Pham (2008), the model can now be formally stated as:

$$
P\left(\pi_{i=j}\right)=\frac{1}{1+e^{-z}}
$$

where $Z=\beta_{\mathrm{o}}+\beta_{1} x_{1}+\beta_{2} x_{2}+\cdots+\beta_{p} x_{p} ; \beta_{0}, \beta_{1}, \ldots, \beta_{p}$ are regression parameters, $x_{0}, x_{1}, \ldots, x_{p}$ are explanatory variables, and $P$ is the probability of household nonfarm enterprise operates with credit access $\left(\pi_{i}\right)$, where $e$ represents the exponential constant approximately 2.718 .

All the independent variables in equation (1) are defined as shown in table 1. The variables are explained as follows:

- $x_{1}$ denotes TRADING, which defines the spending on purchase of 
TABLE 1 Measure of Variables Used in the Binary Logit Regression

\begin{tabular}{|c|c|c|c|}
\hline Variable Name & Variable label & Coding & Exp. sign \\
\hline \multicolumn{4}{|l|}{ Dependent variable } \\
\hline Credit access & CREDIT & $1=$ yes; 0, otherwise & $\mathrm{n} / \mathrm{a}$ \\
\hline \multicolumn{4}{|l|}{ Independent variables } \\
\hline $\begin{array}{l}\text { Spending on purchase of goods } \\
\text { for sale }\left(x_{1}\right)\end{array}$ & TRADING & $1=$ yes; 0, otherwise & $( \pm)$ \\
\hline Physical capital stock $\left(x_{2}\right)$ & STOCK & $1=$ yes; 0, otherwise & $( \pm)$ \\
\hline Gender of employee $\left(x_{3}\right)$ & GENDER & $1=$ male $; 0$ otherwise & $( \pm)$ \\
\hline Main start-up capital source $\left(x_{4}\right)$ & START-UP & $1=$ Borrow $; 0$, otherwise & $( \pm)$ \\
\hline $\begin{array}{l}\text { Spending on other business } \\
\text { costs }\left(x_{5}\right)\end{array}$ & $\cos \mathrm{T}$ & $1=$ yes; 0, otherwise & $( \pm)$ \\
\hline Purchase of raw materials $\left(x_{6}\right)$ & MATERIAL & $1=$ yes; 0, otherwise & $( \pm)$ \\
\hline
\end{tabular}

Notes Based on data from General Household Survey (National Bureau of Statistics 2018).

goods for sale of a nonfarm enterprise. It is a categorical variable for which 1 denotes 'yes' if there is existence of spending on purchase of goods for sale by the household nonfarm enterprises, while 'o, otherwise' represents that there is no existence of spending on purchase of goods for sale by the household nonfarm enterprises.

- $x_{2}$ denotes sтоск, which describes the current value of physical capital stock for household nonfarm enterprise. This is a binary variable that takes a value of 1 for 'yes' (if the enterprise has current value of physical capital stock) and 'o, otherwise' (if the enterprise did not have current value of physical capital stock).

- $x_{3}$ denotes GENDER, which stands for the gender of the employee. It is also a binary variable that takes a value of 1 for 'yes' if the household nonfarm enterprise is a male employee and 'o, otherwise' if the household nonfarm enterprise is female employee.

- $x_{4}$ denotes START-UP, which represents the main start-up capital source by household nonfarm enterprise. It is a dummy variable that takes a value of $1=$ Borrow if the main start-up capital source is borrowed and if the main start-up capital source is not borrowed represents 'o, otherwise'.

- $x_{5}$ denotes $\cos \mathrm{T}$, which describes the spending on other business costs by household nonfarm enterprises. It is a binary variable taking a value of 1 for 'yes' if the enterprise has expenditure for other 
TABLE 2 Distribution of Main Start-up Capital and Credit Access by Sector

\begin{tabular}{|c|c|c|c|c|c|c|}
\hline \multirow[t]{2}{*}{ Varisbles } & \multicolumn{2}{|c|}{ Non-credit access } & \multicolumn{2}{|c|}{ Credit access } & \multicolumn{2}{|c|}{ Total } \\
\hline & (1) & (2) & (1) & (2) & (1) & (2) \\
\hline Borrower & 23 & 15 & 9 & 14 & 32 & 29 \\
\hline Non-borrower & 57 & 73 & 20 & 33 & 77 & 106 \\
\hline Total & 80 & 88 & 29 & 47 & 109 & 135 \\
\hline
\end{tabular}

NOTES Column headings are as follows: (1) urban areas, (2) rural areas. Based on data from National Bureau of Statistics (2018).

business costs and 'o, otherwise' if Non-expenditure on other business costs.

- $x_{6}$ denotes MATERIAL, which describes the purchase of raw materials by household nonfarm enterprises. This is a binary variable that takes a value of 1 for 'yes' (if the enterprise had a purchase of raw material) while 'o, otherwise' denotes that the enterprise did not have a purchase of raw materials.

The credit access which is denoted by CREDIT is a dependent variable. It is a binary variable taking a value of 1 for 'yes' (implying that the enterprise has credit access) and 'o, otherwise' implying that the enterprise does not have credit access.

\section{Results and Discussion}

\section{DESCRIPTIVE ANALYSIS}

The quantitative analysis as indicated in table 2 describes the relationship between the main start-up capital source and credit access of household nonfarm enterprises. Table 2 reports that those household nonfarm enterprises who do not borrow for their main start-up capital source have more shares of participants in credit access while those that borrow as the start-up source have a very small share of participants in credit access in both urban and rural areas. This implies that those who do not borrow (non-borrowers) in household nonfarm enterprises are commonly found in both urban and rural areas.

Table 3 illustrates the percentage and relationship between the main start-up capital source and credit access of household nonfarm enterprises. Table 3 reports that the household nonfarm enterprises that are classified as 'non-borrower' concerning the main start-up capital source have a greater percentage of participants in credit access, but reports a 
TA B LE 3 Main Start-up Capital Source and Credit Access by Percentage Share

\begin{tabular}{|c|c|c|c|c|c|c|}
\hline \multirow[t]{2}{*}{ Varisbles } & \multicolumn{2}{|c|}{ Non-credit access } & \multicolumn{2}{|c|}{ Credit access } & \multicolumn{2}{|c|}{ Total } \\
\hline & (1) & (2) & (1) & (2) & (1) & (2) \\
\hline Borrower & 28.8 & 17.0 & 31.0 & 29.8 & 29.4 & 21.5 \\
\hline Non-borrower & 71.2 & 83.0 & 69.0 & 70.2 & 70.6 & 70.5 \\
\hline Total & 100.0 & 100.0 & 100.0 & 100.0 & 100.0 & 100.0 \\
\hline
\end{tabular}

NOTES Column headings are as follows: (1) urban areas, (2) rural areas. Based on data from National Bureau of Statistics (2018).

smaller percentage of participants in credit access for household nonfarm enterprises operating with borrowing in both urban and rural areas. Conversely, household nonfarm enterprises who do not borrow as a main start-up capital source have a greater percentage of participants in credit access than those of the households that borrow in both urban and rural areas. This implies that the household nonfarm enterprises whose main start-up capital source is through borrowing originating from sources such as a bank loan, NGO support, money lender, or remittance from abroad, among others, have less access to credit as the main source of start-up capital for investment.

\section{RESULTS}

Table 4 presents estimated results of the binary logit model of main startup capital source and credit access of household nonfarm enterprises. The main focus of the result is to ascertain how main start-up capital source influences credit access participation of household nonfarm enterprises.

The table shows the results of the coefficient values and $p$-values of binary logit regression, with two categories of credit access, using 'No credit access' as the bench category variable. The estimated covariates in the study include trading, stock, gender, cost and material. The results indicate that the coefficient of main start-up capital source (START-UP) is a positive and relevant indicator influencing credit access of household nonfarm enterprises. The $p$-value of 0.073 indicates that it is significant at the $10 \%$ level. This finding suggests that higher the household non-farm enterprises borrowed as main start-up capital source, the higher will be the probability of household nonfarm enterprise to participate in credit access. This finding supports the empirical findings of Blanchflower and Evans (2004), which indicate that main start-up capital sources by household nonfarm enterprises do influence credit access participation by these 
TABLE 4 Results of Binary Logit Regression

\begin{tabular}{lrrrr}
\hline Variables & $(1)$ & $(2)$ & $(3)$ & $(4)$ \\
\hline TRADING & 0.597 & 0.381 & 0.117 & 1.817 \\
STOCK & 2.145 & 1.061 & $0.043^{\star *}$ & 8.544 \\
GENDER & -0.537 & 0.488 & 0.272 & 0.584 \\
START-UP & 0.602 & 0.336 & $0.073^{\star}$ & 1.826 \\
COST & -0.718 & 0.311 & $0.021^{\star *}$ & 0.488 \\
MATERIAL & -0.375 & 0.353 & 0.288 & 0.687 \\
INTERCEPT & -3.201 & 1.117 & 0.004 & 0.041 \\
\hline
\end{tabular}

NOTES Observation: 244 , pseudo $R^{2}$ : 0.116 , correctly predicted: 76.6 , dependent variable: credit access. Column headings are as follows: (1) $B$ - relative risk ratio value, which represents the estimated coefficients, (2) robust standard error, (3) probability value of estimated model, (4) exponential of $B$ (coefficient). ${ }^{*}$ and ${ }^{*}$ indicate the significance level at $1 \%$ and $5 \%$.

enterprises. Here main start-up capital source remains a way forward in obtaining such credit accessibility.

The results of the binary model also indicate that physical capital stock (sTOCK) of household nonfarm enterprises influences credit access. The $p$-value of 0.043 , which is significant at the $5 \%$ level, shows that physical capital stock is another important factor. This finding indicates that the higher the physical capital stock of the enterprise, the higher the tendency that household nonfarm enterprises would have credit access, which is consistent with Stiglitz and Weiss (1981). The results also revealed that spending on other business costs by household nonfarm enterprises has a negative and significant influence on credit access, with a $p$-value of 0.021 , which is significant at the $5 \%$ level. This finding is in conformity with the study by Asimakopoulos, Samitas, and Papadogonas (2009).

However the results of this study show that several factors, such as spending on the purchase of goods for sale (TRADING), gender of employee (GENDER) and purchase of raw materials (MATERIAL) are not significant and do not influence household nonfarm enterprise credit access. At this present time of the pandemic, main start-up capital sources and credit access participation were getting worse for many household nonfarm enterprises in developing countries resulting from Covid-19, as the majority of the financial institutions are restricted in issuing credit for their operation. However, the finding of this study shows that main start-up capital source is a relevant factor that could influence credit access participation by household nonfarm enterprise in Nigeria. But at this 
recent period of the pandemic, there was a serious meltdown in various sectors of the economy resulting from low turnout for credit accessibility by household nonfarm enterprises. This challenge of the pandemic has resulted in a great impediment to the performance of enterprises, such as high cost of commodities in the market, high dependence on the government for survival, and poverty.

All these have contributed to a serious negative impact on credit access participation by household nonfarm enterprises in Nigeria. However, numerous studies have been well documented in the literature about the challenges economies face as a result of the Covid-19 pandemic (AppiahOtoo 2020; Polemis and Soursou 2020; Shen et al. 2020). Their studies show that the Covid-19 pandemic affected the operation of firms through production and distribution costs which negatively put a serious pressure on the part of supply, thereby undermining firms' ability to meet set targets for profit making and loan repayment to the lender with interest accrued on it.

\section{Concluding Remarks}

This study estimated the impact of main start-up capital sources on credit access participation by household nonfarm enterprises in Nigeria using the dataset contained in the 2018 General Household Survey (National Bureau of Statistics 2018). The study used quantitative measures such as descriptive analysis and binary logistic regression to unveil the factors that influence credit access participation by household nonfarm enterprise in Nigeria. The results reveal that the main start-up capital source, current value of physical capital stock and spending on other business costs are significant drivers for credit access participation by household nonfarm enterprises in developing countries like Nigeria. Other covariates estimated in the study under review are spending on purchase of goods for sale, other business costs and gender of employee. The results reveal that the roles of these covariates as drivers of credit access participation by household nonfarm enterprises have not shown any significant impact.

However, an important strategy noticed in the dataset shows that the household nonfarm enterprises whose main start-up capital source does not come from borrowing have more participants in credit access in urban and rural areas. These findings imply that there is a need for adequate policies that can put in order the issues of main start-up capital source, current value of physical capital stock and spending for other 
business costs by household nonfarm enterprises in Nigeria. Such government policies are expected to provide for these enterprises not only to participate in credit access but also to sensitise the need for borrowing as a main start-up capital source. Lastly, where government financial support is made available to household nonfarm enterprises, there should be adequate and regular monitoring to ensure that such funds that were provided are not misused for other unimportant uses. This, in turn, will ensure the efficiency and sustainability of household nonfarm enterprises in Nigeria.

\section{References}

Adepoju, A. O., O. K. Omolade, and O. A. Obayelu. 2019. 'Does Credit Constraint in Agriculture Influence Choice of Nonfarm Activities? Evidence from Rural Nigeria.' International Journal of Development and Sustainability 8 (5): 329-45.

Afrin, S., N. Islam, and S. U. Ahmed. 2009. 'A Multivariate Model of Micro Credit and Rural Women Entrepreneurship Development in Bangladesh.' International Journal of Business and Management 3 (8): 169-85

Aga, G. A., and B. Reilly. 2011. 'Access to Credit and Informality among Micro and Small Enterprises in Ethiopia.' International Review of Applied Economics 25 (3): 313-29.

Ajani, L., and N. Omonona. 2009. 'Effects of Social Capital on Credit Access among Cocoa Farming Households in Osun State, Nigeria.' Agricultural Journal 4 (4): 184-91.

Akanni, L., and S. Gabriel. 2020. 'The Implication of Covid-19 Pandemic on the Nigerian Economy.' Centre for the Study of the Economies of Africa. http://cseaafrica.org/the-implication-of-covid19-on-the -nigerian-economy

Ali, M., and J. Peerlings. 2012. 'Farm Households and Non-Farm Activities in Ethiopia: Does Clustering Influence Entry and Exit?' Agricultural Economics 43 (3): 253-66.

Anyanwu, J. 1994. 'Women's Education and the Use of Bank Credit in Nigeria: Challenges for the Twenty-First Century.' Journal of Social Development in Africa 9 (2): 45-59.

Appiah-Otoo, I. 2020. 'Does Covid-19 Affect Domestic Credit? Aggregate and Bank Level Evidence From China.' Asian Economics Letters 1 (3). https://doi.org/10.46557/001c.18074.

Asimakopoulos, I., A. Samitas, and T. Papadogonas. 2009. 'Firm Specific and Economy Wide Determinants of Firm Profitability: Greek Evidence Using Panel Data.' Managerial Finance 35 (11): 930-9. 
Astari, D. W., and Kismiantini. 2019. 'Analysis of Factors Affecting the Health Insurance Ownership with Binary Logistic Regression Model.' Journal of Physics: Conference Series 1320. https://doi.org/10.1088/17426596/1320/1/012011.

Aver, B. 2008. 'An Empirical Analysis of Credit Risk Factors of the Slovenian Banking System.' Managing Global Transitions 6 (3): 317-34.

Bauchet, J., and J. Morduch. 2013. 'Is Micro too Small? Microcredit vs. SME Finance.' World Development 43:288-97.

Beck, T., and A. Demirguc-Kunt. 2005. 'Small and Medium-Size Enterprises.' Journal of Banking and Finance 30 (11): 2931-43.

Benston, G. J., and C. W. Smith. 1976. 'A Transactions Cost Approach to the Theory of Financial Intermediation.' Journal of Finance 31 (2): 215-31.

Bigsten, A., P. Collier, S. Dercon, B. Gauthier, M. Fafchamps, J. Gunning, and A. Zeufack. 2003. 'Credit Constraints in Manufacturing Enterprises in Africa.' Journal of African Economies 12 (1): 25-104.

Blanchflower, D., and D. Evans. 2004. 'The Role of Credit Cards in Providing Financing for Small Busineses.' Payment Card Economics Review 2 (1): 75-95.

Chauke, P. K., M. L. Motlhatlhana, T. K. Pfumayaramba, and F. D. K. Anim. 2013. 'Factors Influencing Access to Credit? A Case Study of Smallholder Farmers in the Capricorn District of South Africa.' African Journal of Agricultural Research 8 (7): 582-5.

Chinanuife, E., S. I. Madueme, A. Orji, and O. I. Anthony-Orji. 2019. 'Empirical Determination of the Causal Link between Private Sector Credit and Manufacturing Output in Nigeria.' Journal of Advanced Research in Management 1 (19): 44-51.

Chisasa, J. 2019. 'Determinants of Access to Bank Credit by Smallholder farmers: Evidence from South Africa.' Academy of Accounting and Financial Studies Journal 23 (4): 1-10.

Chowdhury, M., and Z. Alam. 2017. 'Factors Affecting Access to Finance of Small and Medium Enterprises (smes) of Bangladesh.' USV Annals of Economics and Public Administration 2 (26): 55-68.

Erasmus, P., and R. Scheepers. 2008. 'How Internal and External Sources of Knowledge Contribute to Firms' Innovation Performance.' Managing Global Transitions 6 (3): 277-99.

Essien, U. A., and C. J. Arene. 2014. 'An Analysis of Access to Credit Markets and the Performance of Small Scale Agro-Based Enterprises in Niger Delta Region of Nigeria.' International Journal of Food and Agricultural Economics 2 (3): 105-20.

Etumeahu, H. E., C. C. Okekeke, and C. K. Ukwandu. 2009. 'Small Business Problems in Nigeria: A Comparison with Sweden.' Master Thesis, School of Management, Blekinge Institute of Technology. 
Gamage, P. 2013. 'Determinants of Access to Bank Finance for Small and Medium-Sized Enterprises: The Case of Sri Lanka.' Corporate Ownership \& Control 10 (3): 402-9.

Haggblade, S., P. Hazell, and T. Reardon. 2007. Transforming the Rural NonFarm Economy: Opportunities and Threats in the Developing World. Baltimore, MD: Johns Hopkins University Press.

Haruna, D. 2007. 'Micro Finance: The Financial System That Works for the Majority. The Nigerian Micro Finance Newsletter 5 (8): 5.

Herkenhoff, K. F. 2019. 'The Impact of Consumer Credit Access on Unemployment.' The Review of Economic Studies 86 (6): 2605-42.

Hoff, K., and J. E. Stiglitz. 1990. 'Introduction: Imperfect Information and Rural Credit Markets: Puzzles and Policy Perspectives.' World Bank Economic Review 4 (3): 235-50.

Hoff, K., and J. E. Stiglitz. 20oo. 'Modern Economic Theory and Development.' In Frontiers in Development Economics, edited by G. M. Meier and J. E. Stiglitz, 389-486. 3rd ed. New York: World Bank and Oxford University Press.

Justino, P., J. Litchfield, and H. T. Pham. 2008. 'Poverty Dynamics During Trade Reform: Evidence from Rural Vietnam.' Review of Income and Wealth 54 (2): 166-92.

Kpokiri, E. E., D. G. Taylor, and F. J. Smith. 2020. 'Development of Antimicrobial Stewardship Programmes in Low and Middle-Income Countries: A Mixed-Methods Study in Nigerian Hospitals.' Antibiotics 9 (4): 204. https://doi.org/10.3390antibiotics9040204

Lanjouw, P. 2007. 'Does the Rural Nonfarm Economy Contribute to Poverty Reduction?' In Transforming the Rural Nonfarm Economy: Opportunities and Threats in the Developing World, edited by S. Haggblade, P. B. R. Hazell, and T. Reardon, 55-79. Baltimore, MD: Johns Hopkins University Press.

Loening, J., B. Rijkers, and M. Söderbom. 2008. 'Nonfarm Microenterprise Performance and the Investment Climate: Evidence from Rural Ethiopia.' Policy Research Working Papers 4577, World Bank, Washington, DC.

Luan, D., and S. Bauer. 2016. 'Does Credit Access Affect Household Income Homogeneously Across Different Groups of Credit Recipients? Evidence from Rural Vietnam.' Journal of Rural Studies 47 (Part A): 186-203.

Mach, T. L., and J. D. Wolken. 2011. 'Examining the Impact of Credit Access on Small Firm Survivability. Finance and Economics Discussion Series 35. Board of Governors of the Federal Reserve System, Washington, DC.

National Bureau of Statistics. 2018. 'Nigeria-General Household Survey, 
Panel 2018-2019, Wave 4.' https://microdata.worldbank.org/index .php/catalog/3557

Nwosu, E. O., and A. Orji. 2016. 'Access to Formal Credit and Enterprises Performance in Nigeria: A Gender Perspective.' Argumenta Oeconomica 36 (1): 191-224.

Nwosu, E. O., and A. Orji. 2017. 'Addressing Poverty and Gender Inequality through Access to Formal Credit and Enhanced Enterprise Performance in Nigeria? An Empirical Investigation.' African Development Review 29 (s1): 56-72.

Nwosu, E., A. Orji, N. E. Urama, C. Emecheta, O. Q. Chukwuma, and J. N. Chukwuma. 2020. 'Social Capital, Credit Access and Household Nonfarm Enterprises in Nigeria: A New Empirical Evidence.' Forum for Social Economics. https://doi.org/10.1080/07360932.2020.1825983

Oboh, N., and U. Kushwaha. 2009. 'Socio-Economic Determinants of Farmers' Loan Size in Benue State, Nigeria.' Journal of Applied Sciences Research 5 (4): 354-58.

Ojonta, O., and J. Ogbuabor. 2021. 'Credit Access and the Performance of Non-Farm Household Enterprises: Evidence from Nigerian Data.' International Journal of Sustainable Economy 13 (1): 72-86.

Olagunju, F. I. 2007. 'Impact of Credit Use on Resource Productivity of Sweet Potatoes Farmers in Osun-State, Nigeria.' Journal of Social Sciences 14 (2): 177-8.

Ololade, R. A., and F. I. Olagunju. 2013. 'Determinants of Access to Credit among Rural Farmers in Oyo State, Nigeria.' Global Journal of Science Frontier Research 13 (2): 17-22.

Orji, A., J. E. Ogbuabor, E. C. Ugwu, and O. I. Anthony-Orji. 2019. 'Cash Reserve Requirement and Credit to smes in Nigeria: An A RDL Bounds Test Approach.' Journal of Asian Business Strategy 9 (1): 10-28.

Osano, H. M., and H. Languitone. 2016. 'Factors Influencing Access to Finance by smes in Mozambique: Case of smes in Maputo Central Business District.' Journal of Innovation and Entrepreneurship 5 (13). https://doi.org/10.1186/s13731-016-0041-o.

Polemis, M., and S. Soursou. 2020. 'Assessing the Impact of the Covid19 Pandemic on the Greek Energy Firms: An Event Study Analysis.' Energy Research Letters 1 (3). https://doi.org/10.46557/oo1c.17238

Quach, M. H., and A. W. Mullineux. 2007. 'The Impact of Access to Credit on Household Welfare in Rural Vietnam.' Research in Accounting in Emerging Economies 7:279-307.

Rahji, M. A. Y., and A. I. Adeoti. 2010. 'Determinants of Agricultural Credit Rationing by Commercial Banks in South-Western, Nigeria.' International Research Journal of Finance and Economics 37:7-14.

Sahu, S. K. 2017. 'Firm Performance and Diversification: An Empirical In- 
vestigation of Chemical Sector in India.' International Journal of Sustainable Economy 9 (1): 56-71.

Shen, H., M. Fu, H. Pan, Z. Yu, and Y. Chen. 2020. 'The Impact of the COVID-19 Pandemic on Firm Performance.' Emerging Markets Finance and Trade 56 (10): 2213-30.

Stiglitz, J., and A. Weiss. 1981. 'Credit Rationing in Markets with Imperfect Information. The American Economic Review 71 (3): 393-410.

Ugwuanyi, H. C. 2012. 'Access to and Impact of Credit on Households Welfare in Nigeria.' Master Thesis, University of Nigeria.

Urama, N. E., and C. O. Iheonu. 2019. 'Addressing Poverty Challenges in Nigeria.' AfriHeritage Policy Brief, no. 21.

Verbeek, M. 2004. A Guide to Modern Econometrics. 2nd ed. Chichester: Wiley. 